\title{
SEBUAH SINTESIS PADALITERATUR: STRATEGI INTERVENSI PEMASARAN HIJAU MENUJU PEMBANGUNAN BERKELANJUTAN (A Synthesis of Literature: A Green Marketing Intervention Strategy towards Sustainable Development)
}

\author{
Sri Widyastuti \\ Manajemen, Fakultas Ekonomi dan Bisnis, Universitas Pancasila \\ widyastuti.sri@univpancasila.ac.id
}

Diterima 28 April 2019, Disetujui 01 Mei 2019

\begin{abstract}
Abstrak
Makalah ini menjabarkan literatur tentang strategi intervensi pemasaran hijau dalam rangka menuju pembangunan berkelanjutan dengan penekanan pada strategi intervensi pemasaran hijau pada permasalahan lingkungan yang dihadapi dunia saat ini. Tujuan Pembangunan Berkelanjutan (SDGs) dalam KTT Perserikatan Bangsa-Bangsa (PBB) bersejarah sudah resmi diberlakukan. Selama lima belas tahun ke depan, dengan ini target baru yang universal berlaku untuk semua, negara akan memobilisasi upaya untuk mengakhiri segala bentuk kemiskinan, melawan ketidaksetaraan dan mengatasi perubahan iklim. Kajian ini menjelaskan bahwa baik individu maupunorganisasi dapat mengambil manfaat dari strategi pemasaran yang ramah lingkungan. Kekhawatiran publik atas kerusakan lingkungan dalambeberapa tahun terakhir telah membuat pemasar mengakui kebutuhan dan nilai pemasaran ramah lingkungan. Perhatian pada kondisi tersebut telah mengubah paradigma pandangan perusahaan, pemasar, dan konsumen untuk memberi kontribusi pada perubahan menuju kebaikan bagi alam itu sendiri. Dalam lingkungan bisnis yang kompetitif saat ini, perusahaan yang berorientasi profit dan tanggung jawabsosial sudah mulai mengadopsi konsep pemasaran hijau dan mengatasi isu-isu lingkungan sebagai sumber keunggulan kompetitif. Kelemahan dan masa depan intervensi pemasaran hijau juga menjadi tinjauan penting bagi para peneliti selanjutnya. Dengan demikian pada saat yang sama dapat melindungi lingkungan untuk mencapai pembangunan berkelanjutan.
\end{abstract}

Kata Kunci : Pemasaran Hijau, Pemasaran Berkelanjutan, Pembangunan Berkelanjutan.

\begin{abstract}
This paper describes the literature on green marketing intervention strategies in the framework of sustainable development with an emphasis on green marketing intervention strategies on the environmental problems facing the world today. The Sustainable Development Goals (SDGs) at the historic United Nations (UN) Summit has been officially enacted. For the next fifteen years, with this new universal target valid for all, the country will mobilize efforts to end all forms of poverty, fight inequality and overcome climate change. This study explains that both individuals and organizations can benefit from environmentally friendly marketing strategies. Public concerns over environmental damage in recent years have made marketers recognize the needs and marketing value of environmentally friendly. Attention to these conditions has changed the paradigm of the views of companies, marketers, and consumers to contribute to change towards goodness for nature itself. In today's competitive business environment, profit-oriented and socially responsible companies have begun to adopt the concept of green marketing and address environmental issues as a source ofcompetitive advantage. The disadvantages and future of green marketing interventions are also important reviews for future researchers. Thus at the same time can protect the environment to achieve sustainable development.
\end{abstract}

Keywords: Green Marketing, Sustainable Marketing, Sustainable Development. 


\section{PENDAHULUAN}

Konferensi Perserikatan Bangsa-Bangsa tentang Lingkungan dan Pembangunan (UNCED), yang diadakan di Rio de Janeiro pada tahun 1992 berfokus pada pengintegrasian perlindungan lingkungan dengan pembangunan ekonomi untuk mewujudkan pembangunan berkelanjutan. Konsep pembangunan berkelanjutan merupakan kesepakatan hasil KTT Bumi yang di dalamnya terkandung 2 gagasan penting, yaitu: gagasan kebutuhan, khususnya kebutuhan pokok manusia untuk menopang kehidupan. Dan gagasan keterbatasan, yaitu keterbatasan kemampuan lingkungan untuk memenuhi kebutuhan baik masa sekarang maupun masa yang akan datang. Pada KTT Bumi inilah pertama kali disorot bahwa bisnis dan industri harus memainkan peran penting dalam mewujudkan Pembangunan berkelanjutan (Program Lingkungan Perserikatan Bangsa-Bangsa, Bisnis Berkelanjutan, 1998). Memang kekhawatiran publik atas kerusakan lingkungan dalam beberapa tahun terakhir telah membuat pemasar mengakui kebutuhan dan nilai pemasaran ramah lingkungan. KTT Bumi yang pertama kali tersebut menekankan bahwa bisnis dan industri harus memainkan peran penting dalam mewujudkan pembangunan berkelanjutan.

Dalam implementasinya, ada beberapa prinsip yang telah disepakati juga diadopsi oleh Indonesia. Prinsip pertama adalah universality. Prinsip ini mendorong penerapan SDGs di semua negara baik negara maju maupun negara berkembang. Dalam konteks nasional, implementasi SDGs akan diterapkan di seluruh wilayah Indonesia. Prinsip kedua adalah integration. Prinsip ini mengandung makna bahwa SDGs dilaksanakan secara terintegrasi dan saling terkait pada semua dimensi sosial, ekonomi dan lingkungan. Prinsip. Berakhirnya MDGs pada 2015 masih menyisakan sejumlah pekerjaan rumah yang harus diselesaikan pada periode Tujuan Pembangunan Berkelanjutan (Sustainable Development Goals/SDGs) yang akan dilaksanakan sampai dengan 2030. Tujuan Pembangunan Milenium (Millennium Development Goals/MDGs) yang telah dilaksanakan selama periode 2000-2015 memang telah membawa berbagai kemajuan. Sekitar 70 persen dari total indikator yang mengukur target MDGs telah berhasil dicapai oleh Indonesia. Akan tetapi, beberapa indikator yang mengukur target dari capaian dan harus mendapatkan perhatian khusus dan beberapa indikator terkait lingkungan.

Target Pembangunan Berkelanjutan (SDGs) dari 2030 Agenda Pembangunan Berkelanjutan - diadopsi oleh para pemimpin dunia di September 2015 dalam KTT Perserikatan Bangsa-Bangsa (PBB) bersejarah - resmi diberlakukan. Selama lima belas tahun ke depan, dengan ini target baru yang universal berlaku untuk semua, negara akan memobilisasi upaya untuk mengakhiri segala bentuk kemiskinan, melawan ketidaksetaraan dan mengatasi perubahan iklim, sambil memastikan bahwa tidak ada yang tertinggal atau "No-one Left Behind". Salah satu bentuk komitmen Indonesia dalam upaya pencapaian Tujuan Pembangunan Berkelanjutan/TPB adalah dengan ditetapkannya Peraturan Presiden nomor 59 tahun 2017 tentang Pelaksanaan Pencapaian Tujuan Pembangunan Berkelanjutan pada tanggal 4 Juli 2017. Hal ini yang menjadi agenda utama Indonesia untuk ТРВ (The 2030 Agenda for Sustainable Development atau SDGs) adalah kesepakatan pembangunan baru yang mendorong perubahanperubahan yang bergeser ke arah pembangunan berkelanjutan berdasarkan hak asasi manusia dan kesetaraan untuk mendorong pembangunan sosial, ekonomi dan lingkungan hidup.

Perhatian pada kondisi tersebut telah mengubah paradigma pandangan perusahaan, pemasar, dan konsumen untuk memberi kontribusi pada perubahan menuju kebaikan bagi alam itu sendiri. Dalam lingkungan bisnis yang kompetitif saat ini, perusahaan yang berorientasi profit dan tanggung jawab sosial sudah mulai mengadopsi konsep pemasaran hijau dan mengatasi isu-isu lingkungan sebagai sumber keunggulan kompetitif dalam mengembangkan dan mempromosikan produk hijau untuk memenuhi permintaan konsumen yang sadar lingkungan. Persepsi hijau dapat mempengaruhi niat konsumen untuk membeli produk hijau, Johnstone \& Tan (2015). Skala Green Management Orientation/GMO yaitu proses hijau, manajemen rantai pasokan hijau, inisiatif kebijakan strategis hijau, konservasi energi proaktif dan inovasi pemasaran hijau memiliki dampak positif dan signifikan terhadap kinerja perusahaan, Hardeep (2014). Cing \& Yu (2013) identitas organisasi hijau yang positif dapat mempengaruhi hijau dan kinerja inovasi dipengaruhi secara tidak langsung melalui komitmen lingkungan dan lingkungan organisasi. Siswono \& Widyastuti (2018) menyatakan bahwa familiaritas konsumen atas produk yang ramah lingkungan dari produk Aqua yang mendorong terbentuknya citra yang positif dipengaruhi oleh semakin meningkatnya pengetahuan ekologi konsumen.

Pemasaran, seperti halnya bidang fungsional bisnis lainnya memiliki peran dalam memberikan solusi, untuk masalah lingkungan yang dihadapi dunia 
saat ini dan untuk mewujudkan pembangunan berkelanjutan (Polonsky et al, 1997). Kekhawatiran publik atas kerusakan lingkungan telah membuat pemasar mengetahui kebutuhan dan nilai pemasaran hijau, namun belum terdapat model kebijakan berwawasan lingkungan yang dapat menjadi acuan dalam pelaksanaan pemasaran hijau. Pemasaran yang berbasis pada kelestarian lingkungan "environmental marketing" merupakan perkembangan baru dalam bidang pemasaran, dan merupakan suatu peluang yang potensial dan strategis yang memiliki keuntungan ganda (multiplier effect) baik pelaku bisnis maupun masyarakat sebagai pengguna, Marhadi, dkk (2013). Pendekatan pemasaran hijau (green marketing approach) pada area produk, harga, distribusi dan promosi dapat meningkatkan integrasi dari isu lingkungan pada seluruh aspek dari aktivitas perusahaan.

\section{Tujuan Makalah}

Makalah ini bertujuan untuk memberikan wawasan tentang konsep, kebutuhan dan pentingnya pemasaran hijau. sejauhmana penerapan green marketing dalam empat elemen dari bauran pemasaran. Tujuan lainnya juga meninjau literatur teoritis tentang strategi pemasaran hijau yang telah atau dapat digunakan oleh organisasi untuk memecahkan masalah lingkungan yang dihadapi dunia saat ini melalui strategi intervensi pemasaran hijau untuk mencapai pembangunan berkelanjutan. Respons bidang bisnis lainnya tidak ditinjau, karena ruang lingkup makalah ini terbatas pada disiplin ilmu pemasaran.

\section{KAJIAN TEORI}

\section{Tinjauan Pustaka Teoritis} Pembangunan Berkelanjutan

Meskipun subjek pembangunan berkelanjutan adalah beberapa tahun terakhir telah banyak sarjana, praktisi dan akademisi telah mendefinisikan konsep ini sebagaimana dibuktikan oleh Pearce, et al (1994). Oleh karena itu, tidak ada definisi pembangunan berkelanjutan yang diterima secara universal. Untuk mengatasi keterbatasan ini, makalah ini akan menggunakan definisi Komisi Dunia untuk Lingkungan dan Pembangunan tahun 1987 yaitu pembangunan berkelanjutan adalah pembangunan yang memenuhi kebutuhan saat ini tanpa mengurangi kemampuan generasi masa depan untuk memenuhi kebutuhan mereka sendiri (Masa Depan Bersama Kita, WCED, 1987).

\section{Komponen Pembangunan Berkelanjutan}

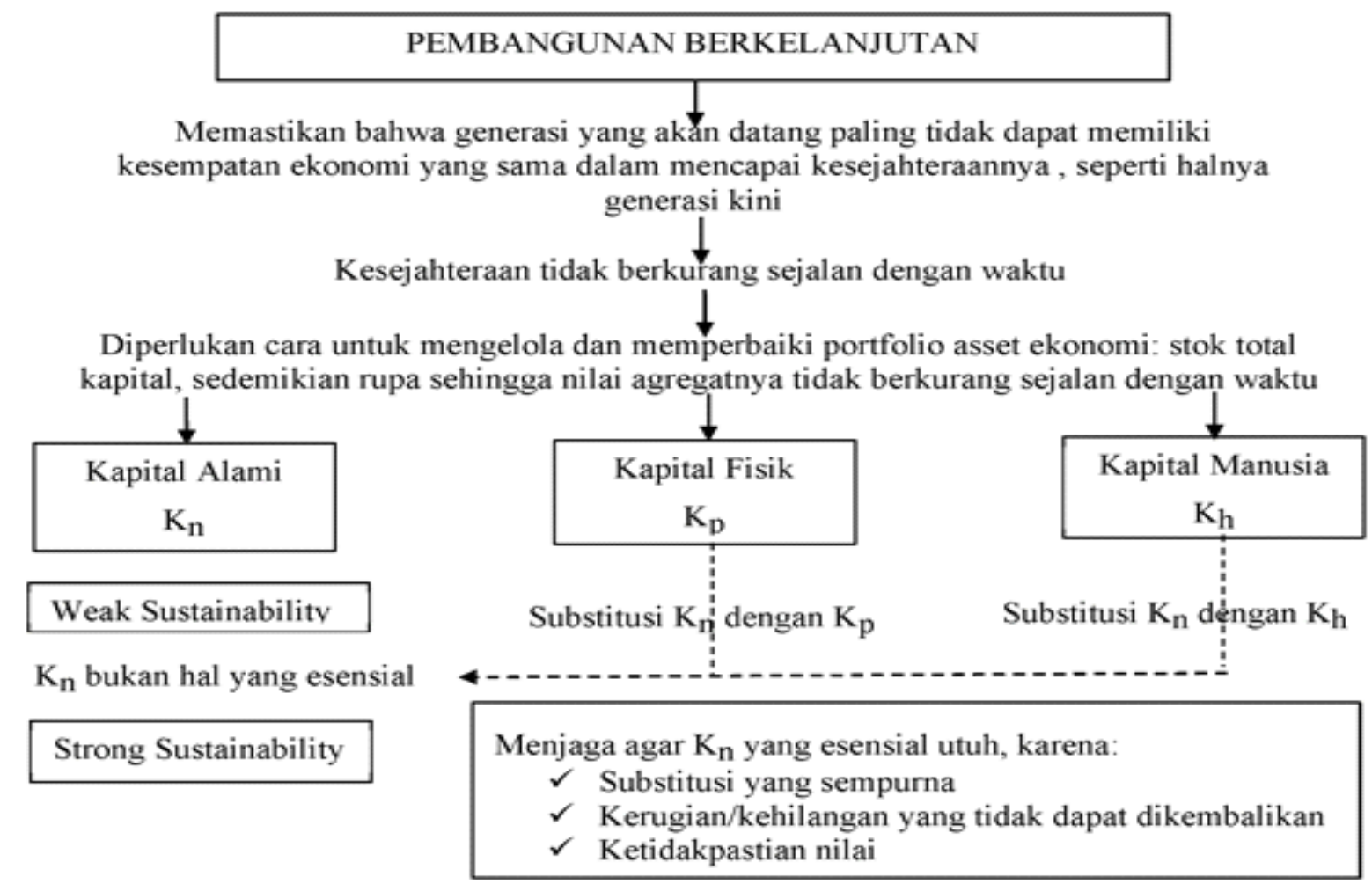

Gambar 1: Sumberdaya Alam dan Pembangunan Berkelanjutan

(dari Pearce and Barbier, 2000) 
Suatu pembangunan, agar dapat berkelanjutan, memiliki suatu persyaratan minimum yang harus dipenuhi yaitu bahwa sediaan kapital alami (natural capital stock) harus dipertahankan sehingga kualitas dan kuantitasnya tidak menurun dalam suatu rentang waktu tertentu (Pearce, 1994). Pemanfaatan sumberdaya alam sebagai natural capital adalah suatu proses substraksi dan/atau penambahan materi dari dan kepada sistem alam (Gunawan, 1994). Proses ini kemudian menyebabkan perubahan ke dalam setiap komponen sistem alam tersebut yang berakibat pada perubahan kondisi alami dari sumberdaya. Dalam sisi skala waktu pemanfaatan relatif terhadap siklus regenerasi atau pemulihan sediaan, sumberdaya alam biasanya dikelompokkan menjadi dua kategori: Sumberdaya tidak pulih dan sumberdaya pulih (Tietenberg, 2000, Hussen, 2000). Komponen pembangunan berkelanjutan menurut Pearce et al (1994) ada 2 yaitu; sediaan kapital alami konstan dan sediaan kapital buatan manusia konstan. Sediaan kapital alami adalah sediaan semua aset lingkungan dan sumber daya alam, dari minyak di tanah hingga kualitas air sosial dan air tanah; dan dari sediaan ikan di lautan hingga kapasitas dunia untuk mendaur ulang dan menyerap karbon. Konsep ekonomi pembangunan berkelanjutan lebih merupakan suatu karakter sistem ekonomi daripada suatu konsep yang dapat diaplikasikan secara langsung. Sehingga dapat disimpulkan bahwa konsep pembangunan berkelanjutan bukan hanya berfokus pada kapital fisik, alami, dan manusia yang merupakan substitusi atau komplemen, tetapi lebih kepada keputusan pengelolaan sumberdaya dalam kondisi ketidakpastian (uncertainty) maupun irreversibility.

Tinjauan Pustaka Teoretis tentang Intervensi Pemasaran Hijau Strategi untuk Pembangunan Berkelanjutan

Organisasi menghadapi upaya memecahkan masalah lingkungan yang dihadapi dunia saat ini yaitu polusi, curah hujan asam, ancaman terhadap lapisan ozon bumi, akumulasi gas rumah kaca, gurun yang memakan lahan pertanian, menipisnya sumber daya alam yang penting, hilangnya hutan hujan dan hilangnya spesies hewan dengan tujuan mencapai pembangunan berkelanjutan Tantangan untuk mencapai keberlanjutan selama beberapa dekade mendatang menurut beberapa ahli memerlukan perubahan radikal dalam seluruh produksi dan konsumsi di masyarakat industri (Ottman, 1999). Para akademisi dan praktisi telah menyarankan strategi pemasaran ramah lingkungan untuk menghadapi tantangan keberlanjutan. Pembangunan berkelanjutan perusahaan dapat dimodelkan dengan mengintegrasikan dimensi pembangunan sosial, ekonomi, dan lingkungan, Chow \& Chen (2012). Strategi-strategi untuk tujuan makalah ini dibagi menjadi dua kategori: Strategi bauran pemasaran dan strategi umum.

Sebagian besar orang percaya bahwa pemasaran ramah lingkungan hanya merujuk pada promosi atau iklan produk dengan karakteristik lingkungan. Istilah seperti bebas fosfat, dapat didaur ulang, dapat diisi ulang, dan ramah terhadap ozon dan ramah lingkungan adalah beberapa hal yang paling sering dikaitkan konsumen dengan pemasaran hijau. Secara umum pemasaran ramah lingkungan adalah konsep yang lebih luas, yang dapat diterapkan pada barangbarang konsumen dan barang-barang industri dan jasa, (Polonsky, 1994). Memang terminologi dan definisi yang digunakan di bidang ini beragam. Terminologinya meliputi; pemasaran hijau, pemasaran lingkungan dan pemasaran ekologis (Polonsky, 1994). Oleh karena itu, tidak ada terminologi dan definisi pemasaran hijau yang diterima secara universal hingga saat ini. Untuk tujuan makalah ini, istilah pemasaran hijau akan digunakan.

Menurut American Marketing Association, pemasaran hijau atau ekologis mengacu pada studi tentang aspek positif dan negatif dari aktivitas pemasaran pada polusi, penipisan energi dan penipisan sumber daya non-energi. Pemasaran ramah lingkungan mengacu pada produk dan paket yang memiliki satu atau lebih dari karakteristik berikut: tidak mengandung zat beracun, lebih tahan lama, mengandung bahan yang dapat digunakan kembali dan/atau terbuat dari bahan yang dapat didaur ulang. Kedua definisi ini memiliki cakupan yang sempit karena berfokus pada sejumlah kecil masalah lingkungan. Pemasaran hijau perlu didefinisikan secara luas, Polonsky (1994) mendefinisikan pemasaran hijau sebagai terdiri dari semua kegiatan yang dirancang untuk menghasilkan dan memfasilitasi setiap pertukaran yang dimaksudkan untuk memenuhi kebutuhan manusia, sehingga kepuasan dari kebutuhan dan keinginan ini terjadi, dengan dampak merugikan minimal pada lingkungan alam. Definisi ini jauh lebih luas dan memasukkan banyak komponen tradisional dari definisi pemasaran konvensional dan juga mencakup perlindungan lingkungan alam.

Pembangunan berkelanjutan membutuhkan “pemasaran berkelanjutan” yaitu upaya pemasaran yang tidak hanya berkelanjutan secara kompetitif tetapi juga berkelanjutan secara ekologis (Polonsky et al, 1997). Memang, peran pemasaran dalam proses 
pengembangan diakui dengan baik. Sebagian besar kegiatan ekonomi dipicu oleh proses pemasaran yang menawarkan dan merangsang konsumsi untuk memenuhi kebutuhan dan keinginan manusia. Namun, peran penting pemasaran dalam pengembangan hanya akan dihargai ketika, melalui pemasaran berkelanjutan, memenuhi kebutuhan saat ini tanpa mengurangi kemampuan generasi mendatang untuk memenuhi kebutuhan mereka sendiri (Polonsky et al, 1997). Di antara strategi utama adalah; strategi produk hijau, strategi logistik hijau, strategi harga hijau, strategi promosi hijau, mengubah konsumen dari budaya konsumsi menjadi konsumen yang peduli secara ekologis, mengadopsi orientasi eko-pemasaran sebagai filosofi bisnis, intervensi pemerintah, analisis inventaris siklus hidup dan bekerja sama untuk sukses (Polonsky et al, 1997; Ottman, 1997; Willum, 1998). Green marketing fokus pada melakukan semua kegiatan pemasaran sambil melindungi lingkungan. Di sisi lain, pembangunan berkelanjutan menuntut agar generasi mendatang mewarisi lingkungan alam dalam kondisi yang sama atau lebih baik seperti yang diwarisi oleh generasi sebelumnya. Oleh karena itu, pembangunan berkelanjutan adalah variabel dependen dari pemasaran hijau dan faktor-faktor lain (Lihat kerangka kerja konseptual pemasaran hijau dan pembangunan berkelanjutan yang menggambarkan hubungan ini, pada Gambar 2).

\section{Strategi Bauran Pemasaran Hijau.}

Strategi bauran pemasaran hijau meliputi pengembangan produk berbasis hijau, logistik hijau, promosi hijau, harga hijau dan konsumsi hijau. Strategi umum tidak terbatas pada disiplin pemasaran tetapi dapat digunakan oleh pemasaran serta area fungsional organisasi lainnya dalam menangani masalah keberlanjutan. Mereka termasuk; adopsi orientasi eko-pemasaran sebagai filosofi bisnis, intervensi pemerintah, melakukan analisis siklus hidup dan bekerja sama untuk sukses (Polonsky et al, 1997; Ottman, 1997; Willum, 1998). Rashad Yazdanifard (2011), menyatakan dalam penelitiannya dampak dari pemasaran hijau pada kepuasan pelanggan dan keamanan lingkungan. Rrevolusi hijau, menuju lingkungan hijau, perlindungan lingkungan, gaya hidup yang berkelanjutan, pengembangan berkesinambungan, melindungi bumi dan banyak lagi telah menjadi fenomena alam dalam kehidupan sehari-hari.

Dalam konsep yang lebih luas green marketing dapat diterapkan untuk barang konsumsi dan barang industri dan jasa, namun keputusan pembelian dan pilihan produk seringkali dipengaruhi oleh dorongandorongan yang sifatnya psikologis. Produk memang tidak dirancang untuk memenuhi kebutuhan fungsionalnya saja, namun juga memuaskan kebutuhan sosial dan psikologi. Green marketing merujuk pada kepuasan kebutuhan, keinginan, dan hasrat pelanggan dalam hubungan dengan pemeliharaan dan pelestarian dari lingkungan hidup. Dengan demikian dalam makalah ini merumuskan sejauhmana penerapan green marketing dalam empat elemen dari bauran pemasaran (produk, harga, promosi, dan distribusi) untuk menjual produk dan pelayanan yang menawarkan keunggulan pemeliharaan lingkungan hidup jangka panjang. Prabandari \& Suasana (2016).

Dengan demikian, pemasaran hijau tidak hanya alat perlindungan lingkungan tetapi juga sebagai strategi pemasaran. Ottman (2011) menyatakan bahwa green market akan semakin bertumbuh dan dewasa (grow \& mature), memanfaatkan peluang akan memberi peluang meningkatkan market share dalam persaingan. Isu lingkungan semakin berkembang dengan pesat di kalangan masyarakat dengan adanya global warming. Meningkatnya perhatian masyarakat membuat semakin banyak perusahaan yang bersedia untuk menerima tanggung jawab lingkungan (environmental responsibility). Strategi green marketing mulai diterapkan, sebagai jawaban terhadap kepedulian produk yang peka pada lingkungannya (Retnawati, 2011). Nanere (2010), mengatakan bahwa green marketing dideskripsikan sebagai usaha organisasi atau perusahaan mendesign, promosi, harga dan distribusi produk-produk yang tidak merugikan lingkungan. Pemasar (marketer) perlu memandang fenomena tersebut sebagai satu hal yang berpotensi sebagai peluang bisnis. 


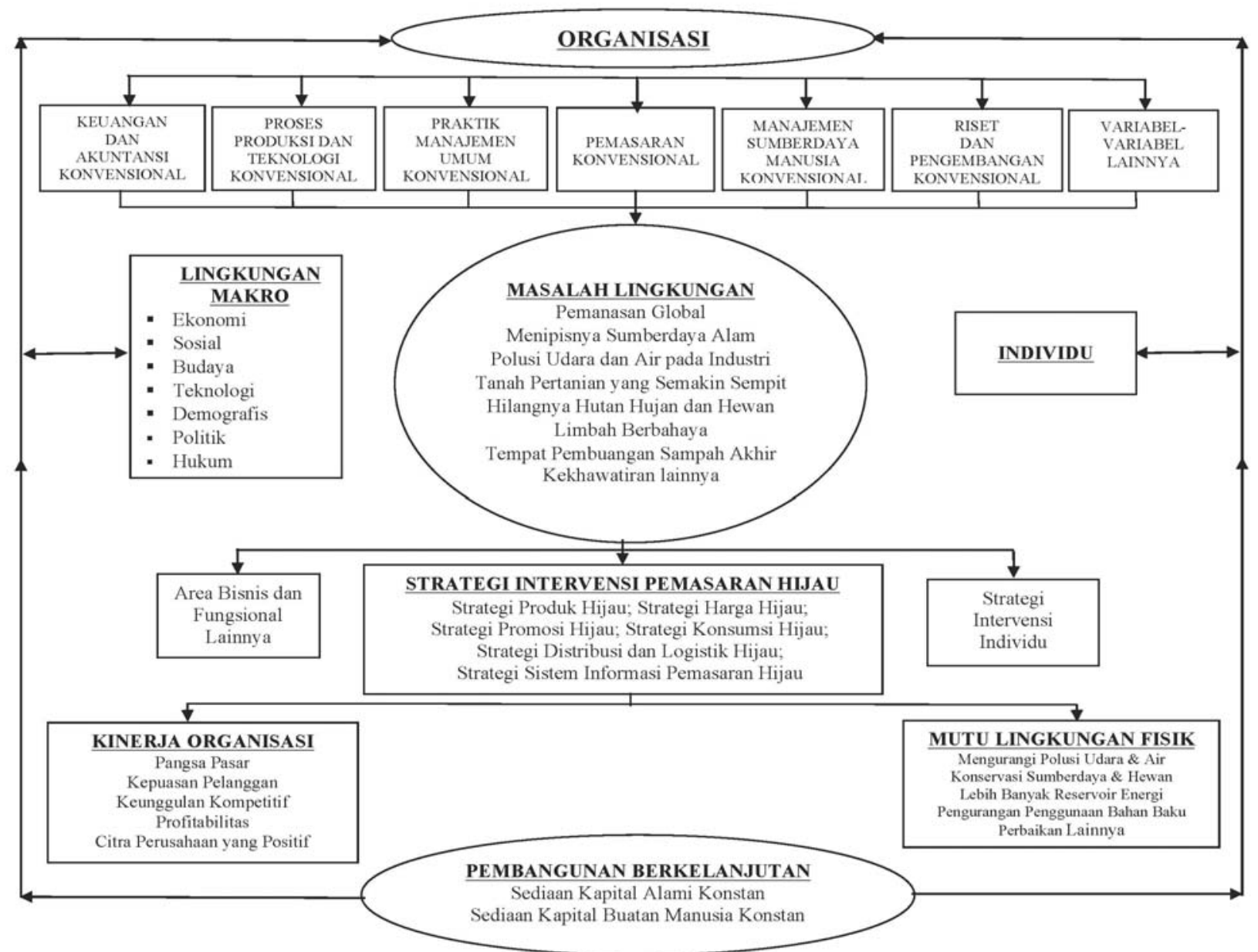

Gambar 2: Kerangka Konseptual Strategi Intervensi Pemasaran Hijau dan Pembangunan Berkelanjutan (modifikasi dariKinoti, 2011)

\section{Strategi Produk Hijau}

Perhatian terhadap isu-isu lingkungan ini ditandai dengan maraknya para pelaku bisnis dalam menerapkan standar internasional atau lebih dikenal dengan ISO-14000. ISO-14000 ini merupakan sistem manajemen lingkungan yang dapat memberikan jaminan (bukti) kepada produsen dan konsumen bahwa dengan memerapkan sistem tersebut produk yang dihasilkan/dikonsumsi baik limbah, produk bekas pakai, ataupun layanannya sudah melalui suatu proses yang memperhatikan kaidah-kaidah atau upayaupaya pengelolaan lingkungan. Menjelaskan juga tentang Reduce berarti mengurangi penggunaan bahan-bahan yang bisa merusak lingkungan. Reduce juga berarti mengurangi belanja barang-barang yang anda tidak "terlalu" butuhkan Reuse sendiri berarti pemakaian kembali, Recycle adalah mendaur ulang barang. Ekolabel (eco-labelling) diartikan sebagai kegiatan pemberian label yang berupa simbol, atribut atau bentuk lain terhadap suatu produk dan jasa. Label ini akan memberikan jaminan kepada konsumen bahwa produk/jasa yang dikonsumsi tersebut sudah melalui proses yang memperhatikan kaidah-kaidah pengelolaan lingkungan. Dengan citra perusahaan hijau yang telah dibangun, orang percaya bahwa perusahaan melakukan bisnis lebih etis dan ramah lingkungan sehingga keputusan pembelian produk/jasa hijau lebih cepat terwujud, Chen \& Lee (2015).

Selanjutnya Larceneux, et al (2011) menyatakan bahwa label organik dapat meningkatkan dampak pada penilaian keseluruhan konsumen pada kualitas dengan mendidik kepekaan mereka terhadap keyakinan ramah lingkungan. Hamid, et al, (2012), melakukan penelitian di Pakistan dan menemukan bahwa konsumen kurang berpengetahuan ekologis dan karenanya tidak ada perubahan terhadap pembelian hijau. Dengan tidak adanya fasilitasfasilitas pokok yang akan diberikan oleh negara, tingkat mereka untuk produk hijau masih belum dikembangkan dan mereka tidak peduli dengan keunggulan produk hijau yang lebih konvensional. Berbeda dengan hasil penelitian Arminda \& Raposo (2008) menunjukkan bahwa ada konsumen di 
Portugis yang membeli produk hijau dan bahwa variabel lingkungan dan demografis tertentu yang signifikan untuk membedakan antara segmen "hijau" dan segmen lainnya. Chen, et al (2015); Nuttavuthisit \& Thøgersen (2017) niat hijau sangat menekankan pada kebutuhan untuk mengelola kepercayaan konsumen sebagai prasyarat untuk pengembangan pasar untuk produk hijau. Menurut Sharma, et al (2015) produk harus dikembangkan tergantung pada kebutuhan pelanggan yang lebih suka produk ramah lingkungan. Peran pemasar dalam manajemen produk termasuk penyediaan desainer produk dengan tren yang digerakkan oleh pasar dan permintaan pelanggan untuk atribut produk ramah lingkungan seperti hemat energi, organik, bahan kimia hijau, sumber lokal, dll. Semakin beragam jenis produk terutama yang terbuat dari bahan pendukung daur ulang pembangunan berkelanjutan dan pengusaha menginginkan untuk mengeksploitasi pasar hijau yang akan muncul.

\section{Strategi Penetapan Harga Hijau}

Harga hijau mempertimbangkan orang-orang, planet dan keuntungan dengan cara yang menjaga kesehatan karyawan dan masyarakat dan memastikan produktivitas yang efisien. Nilai dapat ditambahkan oleh mengubah penampilan, desain produk, fitur, fungsionalitas, dan aplikasi dan melalui kustomisasi. Harga adalah elemen sangat penting dari bauran pemasaran, Sharma, et al (2015). Sebagian besar pelanggan hanya akan siap membayar premi jika ada persepsi nilai produk tambahan. Ini nilai dapat ditingkatkan kinerja, fungsi, desain, daya tarik visual atau rasa. Manfaat lingkungan biasanya merupakan bonus tambahan tetapi akan sering menjadi faktor penentu antara produk yang sama nilai dan kualitasnya. Bertanggung jawab secara lingkungan produk kendaraan hemat bahan bakar, hemat air produk, pencetakan bahan yang tidak berbahaya.

Banyak konsumen berasumsi bahwa produk ramah lingkungan sering dihargai lebih tinggi daripada produk konvensional (Peattie, 1999; Polonsky, 2001). Walaupun anggapan mereka mungkin benar, Peattie (1999) berpendapat bahwa produk-produk ini tidak mahal, tetapi produk konvensional tidak murah secara realistis karena tidak termasuk biaya sosiallingkungan dari produksi, penggunaan dan pembuangan produk. Dia menyarankan bahwa salah satu cara untuk menghadapi kontroversi harga tinggi adalah dengan bertanya kepada konsumen "apakah mereka ingin terus membeli produk murah yang merusak lingkungan?” Implikasi dari hal di atas adalah bahwa konsumen memerlukan informasi lebih lanjut tentang manfaat produk hijau agar dapat memebrikan nilai mereka secara lebih objektif. Ada kebutuhan yang berkembang dan beralih ke produk dan layanan ramah lingkungan oleh pemasar atau konsumen. Meskipun perubahan konsumen menjadi pembelian hijau akan mahal bagi konsumen atau bisnis, itu bisa bermanfaat dalam jangka panjang, Cherian. J., \& Jolly, J. (2012). Widyastuti \& Santoso (2016) menyatakan bahwa sikap pelanggan yang sudah memahami tentang produk hijau, belum ditunjang sepenuhnya oleh perusahaan dalam menerapkan pemasaran hijau dengan memberikan nilai yang lebih baik bagi pelanggannya. Konsumen hanya akan siap untuk membayar tambahan nilai jika ada persepsi tambahan nilai dari produk hijau dan mau membayar pada harga premium, serta mau melakukan pembelian ulang.

\section{Strategi Distribusi dan Logistik Hijau}

Distribusi hijau adalah tentang mengelola logistik untuk dipotong turun pada emisi transportasi, dengan demikian di efek yang bertujuan mengurangi jejak karbon, Sharma, et al (2015). Ini menghindari pengiriman produk dari jauh, sehingga mengurangi biaya pengiriman dan yang lebih penting, karbon konsekuen emisi oleh kapal dan moda pengangkutan lainnya. Pilihan lokasi dan kapan membuat suatu produk tersedia akan berdampak signifikan pada ketertarikan pelanggan. Lokasi juga harus konsisten dengan citra yang diinginkan perusahaan, memproyeksikan dan memungkinkannya untuk memproyeksikan gambarnya sendiri bukannya didominasi atau dikompromikan oleh citra lokasi. Lokasi harus dibedakan dari pesaing perusahaan. Ini dapat dicapai dengan promosi di dalam toko dan tampilan menarik secara visual atau menggunakan daur ulang bahan untuk menekankan ramah lingkungan dan manfaat terkait lainnya.

Bentuk paling umum dari logistik hijau adalah sistem saluran terbalik. Sistem saluran terbalik menangani masalah daur ulang pasca-konsumen. Istilah daur ulang berarti '... untuk mengekstraksi dan menggunakan kembali zat-zat berguna yang ditemukan dalam limbah', Kinoti, (2010) sedangkan pendekatan tradisional untuk pembuangan produk dapat digambarkan sebagai linier di mana bahan limbah dibuang tanpa pandang bulu, Fuller \& Allen (1997). Definisi daur ulang dengan jelas menunjukkan bahwa tujuannya adalah membalikkan hasil ini dengan mencapai aliran sirkuler yang memengaruhi reintegrasi bahan dengan pasar). Sistem saluran terbalik memiliki karakteristik berikut. 
Pertama, konsumen menjadi penjual dan produsen pembeli. Kedua, mereka menekankan pada fungsi penyortiran dan akumulasi. Ketiga, bahan daur ulang dapat mengalir mundur melalui saluran balik ke salah satu dari tiga pasar industri umum: (1) produsen asli, (2) perusahaan di industri penghasil bahan baku; atau (3) industri lain yang dapat menggunakan daur ulang sebagai pengganti bahan utama, dan akhirnya konsumen (penjual) cenderung memainkan peran yang lebih pasif daripada peran proaktif dari penjual tipikal pada saluran konvensional. Komponen lain dari strategi logistik hijau termasuk pengurangan bahan pengemasan untuk secara langsung atau tidak langsung menurunkan biaya distribusi, penggunaan sistem transportasi terintegrasi dan Internet. Namun, lebih banyak penekanan telah diberikan pada sistem saluran terbalik (Willums, 1998; Polonsky, 2001). Namagembe (2016) rantai pasokan manufaktur adalah kontributor yang utama pada pencemaran lingkungan, adopsi praktik hijau adalah cara untuk mengurangi polusi lingkungan, dimana orientasi enviropreneurial/EO secara positif memengaruhi adopsi praktik rantai pasokan hijau.

\section{Strategi Promosi Hijau}

Promosi hijau adalah kegiatan mempromosikan produk yang memiliki karakteristik yang tidak membahayakan lingkungan alam (Polonsky et al, 1997). Dalam lingkungan bisnis yang kompetitif saat ini, perusahaan yang berorientasi profit dan tanggung jawab sosial sudah mulai mengadopsi konsep pemasaran hijau dan mengatasi isu-isu lingkungan sebagai sumber keunggulan kompetitif dalam mengembangkan dan mempromosikan produk hijau untuk memenuhi permintaan konsumen sadar lingkungan. Untuk mempengaruhi minat pembelian dan tindakan pelanggan terhadap produk hijau, hijau pesan iklan harus informatif dan persuasif cukup untuk menurunkan hasil bisnis yang diinginkan ditargetkan. Iklan mengklaim seperti "ramah lingkungan” dan "biodegradable” adalah istilah yang umum tersedia di pasar tetapi efektivitasnya dalam aksi untuk meyakinkan pembelian hijau masih tidak signifikan Tan, Booi-Chen, (2011). Akibatnya, perusahaan telah mulai mengidentifikasi dan memahami faktor-faktor penentu sikap lingkungan dan perilaku pembelian hijau dalam rangka untuk memberikan sebuah iklan yang efektif dan persuasif dalam strategi komunikasi mereka.

Pemasar hijau dapat menarik pelanggan di Internet dasar kinerja, penghematan uang, kesehatan dan kenyamanan, atau sekadar lingkungan keramahan, sehingga menargetkan berbagai macam warna hijau konsumen, Sharma, et al (2015). Kesadaran konsumen dapat diciptakan dengan menyebarkan pesan di antara konsumen tentang manfaat ramah lingkungan produk. Kunci untuk pemasaran hijau yang sukses adalah kredibilitas. Tak pernah melebih-lebihkan klaim lingkungan atau membangun harapan yang tidak realistis, dan berkomunikasi secara sederhana dan melalui sumber yang dipercaya orang, memajukan kredensial dan prestasi hijau mengumumkan cerita hijau perusahaan dan karyawan inisiatif, berpartisipasi dalam program penghargaan lingkungan untuk profil lingkungan kredensial kepada pelanggan dan pemangku kepentingan.

\section{Manajemen Strategi secara Umum}

Perusahaan pada umumnya memposisikan diri dalam industri, karena merupakan dasar dari strategi bersaing. Strategi bersaing sendiri merupakan sumber dari keunggulan bersaing. Jika perusahaan perlu memposisikan dirinya secara strategis di lingkungan industrinya (market environment), maka seharusnya memposisikan diri secara strategis di non market environment (legal, social, political). Sehingga perusahaan dapat menyeimbangkan dirinya antara posisi yang besifat strategis yang mengarah pada market environment dan juga sekaligus bersifat etis yang mengarah pada non market environment. Turbulensi lingkungan yang ada tidak memberikan pilihan kepada perusahaan selain untuk memulai mempraktekkan manajemen hijau yang berkelanjutan, Rajput, et al (2013). Dengan demikian logo hijau pada produk atau jasa yang dihasilkan perusahaan menunjukkan bahwa produk atau jasa mereka memiliki keunggulan kompetitif. Akibatnya sebagian besar keputusan pembelian pelanggan dipengaruhi oleh label produk hijau, Yazdanifard \& Erdoo (2011).

Tujuan bagi suatu organisasi adalah untuk beroperasi dalam daya dukung ekosistem lingkungan dengan mengurangi polusi dan meminimalkan konsumsi sumber daya dan jejak ekologis korporasi. Keberhasilan organisasi dalam pemasaran hijau atau pemasaran berkelanjutan terletak pada reorganisasi, restrukturisasi, dan pendesainan ulang banyak proses dan sistem dalam organisasi. Bahkan mereka yang berpikir bahwa orang-orang pemasaran saja akan dapat mengembangkan orientasi pemasaran hijau untuk perusahaan adalah salah. Implementasi bisnis yang ramah lingkungan dapat menjadikan perusahaan unggul dalam persaingan, karena produk yang ditawarkan mempunyai nilai tambah yaitu ramah lingkungan dibandingkan pesaingnya. Berdasarkan RBV (resource-based view), perusahaan perlu 
mengeksploitasi kemampuannya untuk dapat bersaing. Melalui green management, perusahaan dapat melakukan inovasi melalui seluruh aktivitasnya agar dapat mendapatkan keunggulan bersaing, Triastity, (2011). Penemuan produk baru yang ramah lingkungan, dapat menjadi differensiasi bagi perusahaan sekaligus etis dari sisi etika bisnis, tanpa harus bersaing langsung dengan pesaing sejenis lainnya. Hal ini sejalan dengan Baron (2003) bahwa lingkungan non-pasar beberapa perusahaan berusaha untuk membedakan diri dari perusahaan lain di industri mereka. Retnawati (2011) menyatakan ada asosiasi kuat antara tindakan perusahaan yang berorientasi lingkungan dan tanggung jawab sosial, karena akan mendorong perilaku pembelian. Dengan demikian strategi bisnis hijau mendorong pembelian, sehingga dapat meningkatkan penerimaan dari penjualan. Menurut Hosein, et al (2011) kegiatan pemasaran hijau akan memungkinkan perusahaan untuk bersinar dibandingkan dengan pesaing mereka dengan menawarkan produk-produk baru dengan keuntungan ekstra, di pasar yang baru.

Sementara Baines, (2012) menyatakan dalam temuannya bahwa ketika masyarakat menjadi semakin peduli dengan masalah lingkungan, perusahaan-perusahaan dengan strategi hijau yang lebih berani cenderung: menjadi pemimpin dalam pengembangan produk baru dan peluang bisnis, memiliki potensi pertumbuhan yang sangat baik, berusaha untuk mempertahankan operasi produksi secara lokal dan memberikan kontribusi positif untuk mengatasi masalah lingkungan. Seperti manajemen kualitas total, pemasaran berkelanjutan membutuhkan keterlibatan karyawan dari semua bidang fungsional, termasuk pemasaran, produksi, pengadaan, sistem akuntansi dan informasi (Polonsky et al, 1997). Ottman (1997) telah menyarankan berbagai strategi yang dapat membantu perusahaan untuk membuat kemajuan yang masuk akal menuju filosofi bisnis yang berorientasi lingkungan.

\section{Strategi Intervensi Pemerintah}

Strategi terkait pemerintah ini direkomendasikan ketika proses pasar bebas tidak cukup mendukung pembangunan berkelanjutan (Polonsky et al, 1997). Melakukan analisis/penilaian inventaris siklus hidup (LCA). Analisis siklus hidup, yang awalnya dikembangkan pada tahun 1970, adalah sebuah pendekatan, yang melibatkan daftar berbagai aspek lingkungan positif dan negatif dari produk tertentu sepanjang siklus hidupnya (Ottman, 1997; Willum, 1998). Analisis ini memperhitungkan dampak lingkungan dari pengadaan, pengemasan, distribusi, penggunaan, dan pembuangan bahan baku. Informasi yang dikumpulkan dari analisis dapat membantu pemasar mengubah cara produk dibuat, dikemas, diangkut, dijual, digunakan kembali, digunakan kembali, didaur ulang dan dibuang atau mengembangkan produk yang sama sekali baru. Meskipun manfaat analisis siklus hidup di atas bisa mahal dan sulit (Ottman, 1997; Willum 1998). Temuan Mei, et al (2012) menyatakan bahwa inisiatif pemerintah memiliki pengaruh yang paling signifikan terhadap niat beli hijau di kalangan konsumen Malaysia.

Bekerja sama dengan semua pemangku kepentingan untuk sukses. Masalah lingkungan yang kompleks tidak dapat diselesaikan oleh organisasi saja; sebaliknya ada kebutuhan dari berbagai pemangku kepentingan masyarakat untuk menyatukan keterampilan, kemampuan, dan sumber daya kolektif mereka. Stakeholder / pemasar harus membentuk kemitraan strategis atau koalisi dengan masyarakat umum, karyawan, pengecer, pemasok, kelompok lingkungan, pendidik, dan pemerintah (Ottman, 1997). Dukungan untuk intervensi pemerintah dalam menangani degradasi lingkungan tersebar luas. Polonsky et al (1997) berpendapat bahwa tangan pemerintah yang terlihat harus membimbing pasar menuju praktik produksi dan konsumsi yang berwawasan lingkungan. Porter \& Kramer (2006) juga mendukung intervensi pemerintah dengan hipotesis mereka bahwa intervensi pemerintah dapat merangsang inovasi. Polonsky et al (1997) mengusulkan empat strategi intervensi pemerintah:

- Perumusan dan adopsi kebijakan regulasi yang mendorong keseimbangan kegiatan ekologi dan ekonomi.

- Mereformasi praktik produksi dan konsumsi melalui mandat dan insentif.

- Partisipasi pemerintah dalam pengadaan, litbang dan kerjasama internasional; dan

- Secara aktif mempromosikan masalah lingkungan dan bermitra dengan industri.

\section{HASIL DAN PEMBAHASAN}

\section{Manfaat Menggunakan Strategi Pemasaran} Hijau dan Manajemen Strategi Umum

Kepedulian lingkungan menghadirkan tantangan dan peluang. Manajer eksekutif yang tercerahkan telah memanfaatkan peluang dengan menggunakan strategi pemasaran ramah lingkungan yang telah menghasilkan berbagai manfaat (Ottman, 1997): Profitabilitas: Produk berbasis hijau menghasilkan lebih sedikit limbah, menggunakan lebih sedikit bahan 
baku, dan menghemat energi. Keunggulan kompetitif: Perusahaan yang mengutamakan inovasi lingkungannya akan menikmati keunggulan kompetitif. Peningkatan pangsa pasar: Loyalitas merek hampir selalu rendah. Produk yang lebih baik: Produk berbasis hijau memiliki kualitas lebih tinggi dalam hal penghematan energi, kinerja, kenyamanan, keamanan, dll. Imbalan Pribadi: Produk hijau menawarkan kepada konsumen manfaat hidup yang lebih sehat, lebih terpenuhi, dan kekuatan untuk menjadikan dunia tempat yang lebih baik. Lingkungan Fisik yang Lebih Baik: Penggunaan semua strategi pemasaran hijau yang terkoordinasi dengan baik akan menghasilkan lingkungan fisik yang lebih baik dalam hal pengurangan polusi udara dan air, penipisan energi limbah, pemanasan global, penggundulan hutan, penipisan sumber daya alam, dan laju penimbunan sampah.

Tantangan Strategi Intervensi Pemasaran Ramah Lingkungan dan Manajemen Strategi Umum

Meskipun banyak manfaat pemasaran ramah lingkungan bukan tanpa kendala/ tantangan. Kelemahannya meliputi, Minoti (2010):

- Secara umum semua strategi pemasaran ramah lingkungan mahal dan sulit diimplementasikan dalam jangka pendek.

- Manfaat lingkungan tidak berwujud, tidak langsung atau tidak penting bagi konsumen. Sebagai contoh, konsumen tidak dapat melihat emisi yang dihemat ketika mereka menggunakan alat hemat energi.

- Manfaat lingkungan sulit diukur atau diukur.

- Beberapa strategi (mis. promosi) dapat dimanipulasi. Misalnya beberapa pemasar menggunakan klaim lingkungan palsu untuk mendapatkan keunggulan kompetitif.

- Keberhasilan pemasaran hijau tergantung pada beberapa pemangku kepentingan yang harus bekerja sebagai tim. Ini termasuk; masyarakat umum, karyawan, pengecer, pemerintah, kelompok lingkungan, dan pemasok. Kelompok mana pun dapat membatalkan tujuan kesepakatan bersama.

- Biaya yang dihemat melalui daur ulang masih diragukan.

\section{SIMPULAN DAN SARAN}

Kelestarian lingkungan bukan hanya masalah kepatuhan untuk menjaga sumber daya alam. Tantangan untuk mencapai pembangunan berkelanjutan selama beberapa dekade mendatang memerlukan perubahan radikal dalam seluruh produksi dan konsumsi di masyarakat industri. Searah dengan tuntutan bisnis yang semakin mengenali banyak keunggulan kompetitif dan peluang bisnis yang bisa diperoleh dari eco-sustainability dan pemasaran hijau, maka dunia menunjukkan bukti bahwa banyak orang mengkhawatirkan tentang lingkungan dan mengubah perilaku pembelian mereka. Akibatnya, ada pertumbuhan pasar yang berkelanjutan dan bertanggung jawab secara sosial pada produk dan layanan. Jenis-jenis bisnis yang ada juga produk yang mereka hasilkan memperlihatkan pendekatan pemasaran sedang berubah. Orangorang umumnya ingin melakukan hal yang benar, jadi tantangan dan peluang bagi pemasar hijau adalah untuk memudahkan orang untuk melakukannya. ketika semua sama-kualitas, harga, kinerja maka manfaat ketersediaan-lingkungan kemungkinan besar akan memberikan tip demi mendapatkan suatu produk yang ramah lingkungan. Makalah ini telah mendukung pemasaran seperti area Fungsional lainnya dari bisnis berkontribusi terhadap masalah lingkungan yang mendukung dunia saat ini. Oleh karena itu, ia memiliki peran dalam mencari solusi untuk masalah lingkungan ini. Makalah ini lebih lanjut tentang pemasaran melalui pemasaran hijau dan khusus strategi pemasaran hijau mengatasi tantangan dengan hasil positif dari peningkatan kinerja organisasi, lingkungan fisik yang lebih baik. Pada akhirnya akan menuju pada pengembangan pemeliharaan ke arah pembanguna berkelanjutan.

\section{DAFTAR PUSTAKA}

Baines, T., Brown, S., Benedettini, O., and Ball, P., (2012), Examining green production and its role within the competitive strategy of manufacturers. Journal of Industrial Engineering and Management, 5(1), 5387 http://dx.doi.org/10.3926/jiem.405.

Baron, D.P., (2003), Business and Its Environment- 4' ed. Prentice Hall, Upper Saddleriver, New Jersey.

Chen, M.F., and Lee, C.L., (2015), The impacts of green claims on coffee consumers' purchase intention. British Food Journal. Vol. 117 No. 1, 2015. pp. 195209. DOI 10.1108/BFJ-07-2013-0196

Chen, Y.S., Lin, C.Y. and Weng, C.S., (2015), The influence of environmental friendliness on green trust: The mediation effects of green satisfaction and green perceived quality, Sustainability, 7, 10135-10152; doi:10.3390/su70810135.

Cherian. J., and Jolly, J. (2012), Green marketing: A study of consumers' attitude towards environment friendly products. Asian Social Science, doi:10.5539/ass. v8 n12 p.117. 
Ching, H,C., and Yu, S.C., (2013), Green organizational identity and green innovation, Management Decision. Vol. 51 No. 5, 2013., pp. 1056-1070. DOI 10.1108/MD09-2011-0314

Chow, W.S., and Chen, Y. (2012), Corporate sustainable development: Testing a new scale based on the Mainland Chinese Context, Journal Business Ethics 105:519-533, Springer Science+Business Media.

Do Pac, A. and Raposo, M., (2009), "Green" segmentation: An application to the Portuguese consumer market, Marketing Intelligence \& Planning Journal, Vol. 27 No. 3, Pp. 364-379.

Fuller, D., and Allen. J., (1997), A Typology of Reverse Channel Systems for Post-Consumer Recyclables. Environmenta Marketing Strategies, Practice, Theory and Research. Edited by Polonsky, M. and Mintu, A., Haworth Press Inc.

Gunawan, I., (1994), A Methodological Approach to Sustainable Resources Utilization in Indonesia: Integrating Geographic Information Systems, Mathematical Modeling, and Expert Systems, unpublished Dissertation, College Station, TX.

Hamid, S.A.R., Ghafoor, H.A., and Shah, T.Z., (2012), Analysis of attitude towards green purchase: Pakistan in context, International Journal of Business and Social Science, Vol. 3 No. 6; p 112

Hardeep, C., Ramesh. D., and Swati. R., (2014), Conceptualisation, development and validation of green marketing orientation (GMO) of SMEs in India. Journal of Global Responsibility. Vol. 5 No. 2, 2014, pp. 312-337. ( ) Emerald Group Publishing Limited 2041-2568 DOI 10.1108/JGR-02-2014-0005

Hosein. V. \& Asadollahi, A., (2011), The role of social responsibility in green marketing \& its effects health \& environment in Iran. European Journal of Social Sciences, Volume 19 Number 4.

Huseen, A.M. (2000), Principles of Environmental Economics: Economics, Ecology, and Public Policy, Routledge, New York.

Hosein. V. \& Asadollahi, A., (2011), The role of social responsibility in green marketing $\&$ its effects health \& environment in Iran. European Journal of Social Sciences, Volume 19 Number 4.

Huseen, A.M. (2000), Principles of Environmental Economics: Economics, Ecology, and Public Policy, Routledge, New York.

Johnstone, M.L. \& Tan, L.P, (2015), Exploring the Gap Between Consumers' Green Rhetoric and Purchasing Behaviour, J Bus Ethics, 132:311-328. DOI 10.1007/ s10551-014-2316-3.

Kinoti, P.M., (2011), Green marketing intervention strategies and sustainable development: A conceptual. International Journal of Business and Social Science Vol. 2 No. 23. Pp. 263-273.
Larceneux, F, Florence, B.M., and Valérie, R., (2011), Why Might Organic Labels Fail to Influence Consumer Choices? Marginal Labelling and Brand Equity Effects, Journal Consum Policy, 35:85-104, \# Springer Science+Business Media, LLC.

Marhadi, Ayu, N., dan Noviasari, H., (2013), Pengaruh strategi green marketing pada bauran pemasaran terhadap keputusan konsumen dalam membeli rumah di Perumahan PT. Asta Karya Pekanbaru, Jurnal Ekonomi. Vol. 21, No. 3, hal 1-15.

Mei, O.J., Ling, K.C., and Piew, T.H. (2012), The antecedents of green purchase intention among Malaysian consumers. Asian Social Science; Vol. 8, No. 13; 2012 ISSN 1911-2017, E-ISSN 1911-2025, published by Canadian Center of Science and Education.

Namagembe, S., Sridharan, R., and Ryan, S., (2016), Green supply chain management practice adoption in Ugandan SME Manufacturing Firms: The role of enviropreneurial orientation. World Journal of Science, Technology and Sustainable Development. Vol. 13 No. 3, pp. 154-173.

Nanere, M., (2010), What green marketing has to offer, International Conference Indonesian Management Scientist Ass (AIMI). La Trobe University, Bendigo, Australia.

Nuttavuthisit, K., and Thøgersen. J., (2017), The importance of consumer trust for the emergence of a market for green products: The case of organic food. J Bus Ethics, 140:323-337. DOI 10.1007/s10551-0152690-5

Ottman J.A, (1999), Achieving Sustainability out of The Box Thinking Regarding Environmentally Preferable Products and Services. Greener Marketing, A Global Perspective on Green Marketing Practice. Edited by Charter M. and Polonsky M, Green leaf Publishing Limited, 1999, 7283.

Ottman, (1997), Green Marketing, Opportunity for Innovation, NTC publishers, 1998.

Ottman, Jacquelyn, A., (2011), The New Rules Of Green Marketing: Strategies, Tools,And Inspiration For Sustainable Branding, Greenleaf-Publishing.

Pearce, D., and Barbier, E., (2000), Blueprint for Sustainable Economy, Earthscan Publications, London.

Pearce, D., et al, (1994), Measuring Sustainable Development, Earth Scan Publication Limited, 1994 pg.3-23.

Pearce, Markandya and Barbier (1994), Blue Print for A Green Economy, Earthscan Publication Limited, pg. $1-50$.

Peattie K., (1999), Shifting to A Greener Paradigm, Greener Marketing, A Global Perspective on Greening Marketing Practice. Edited by Charter, M., and Polonsky. M., Greenleaf Publishing Limited, pg. 57-70. 
Polonsky, and Jay, M., (1994), An introduction to green marketing, Electronic Green Journal, 1(2), Article 3.mgmjp@cc.newcastle.edu.au.

Polonsky, and Jay, M., (2001), Re-evaluating green marketing: A strategic approach, Business Horizons, Vol.44 Issue 5, pg.10,pg.21,

Polonsky, M., and Mintu, A., (1997), The Future of Environmental Marketing: Food For Thought" Environmental Marketing Strategies, Practice, Theory and Research. Haworth. pg. 389-391.

Porter, M. E., and Kramer, M. R., (2006), Strategy \& Society: The Link Between Competitive Advantage and Corporate Social Responsibility. Harvard Business Review, 84(12), 78-92.

Prabandari, A.V., dan Suasana, I.D.K.G., (2016), Pengaruh green marketing dan service value terhadap impulse buying pada Manic Organik Restaurant di Denpasar, E-Jurnal Manajemen Unud, Vol. 5, No. 4, 2016: 21672193 ISSN : 2302-8912.

Rajput, N., Kaura, R., and Khanna, A., (2013), Indian banking sector towards a sustainable growth: A paradigm shift. International Journal of Academic Research in Business and Social Sciences, Vol. 3, No. 1, www.hrmars.com/journals.

Retnawati, B. B. (2011), Peningkatan nilai merek-merek asli Indonesia dengan green branding, Dinamika Sosial Ekonomi, Volume 7 Nomor 1, pp 9.

Sharma, M. K., Pandey, N., dan Sajid, R., (2015), Green marketing : A study of emerging opportunities and challenges in Indian scenario, International Journal of New Technology and Research (IJNTR). ISSN:2454-4116, Volume-1, Issue-4, Pp. 51-57.
Siswono, S., dan Widyastuti, S., (2018) Membentuk citra perusahaan hijau melalui sikap hijau dan pengetahuan ekologi dari konsumen air minum dalam kemasan Aqua. Jurnal Riset Bisnis, Vol 1 (2) hal: 68-77. e ISSN 2598-005X p - ISSN 2581-0863. e-jurnal : http:// jrb.univpancasila.ac.id.

Tan, Booi-Chen. (2011), The Roles Of Knowledge, Threat, And Pce On Green Purchase Behaviour, International Journal Of Business And Management_6. 12 (Dec): 14-27.

Tietenberg, T., (2000), Environment and Natural Resources Economics, Addison-Wesley, Reading, Massachusetts.

Triastity, (2011), Green management sebagai pelaksanaan etika bisnis upaya kelangsungan hidup perusahaan jangka panjang, Jurnal Ekonomi dan Kewirausahaan, Vol. 11, No. 2, Pp 87-95.

Widyastuti, S., dan Santoso, B., (2018), Green marketing: A study of the factors influencing the repurchase decision for Javanony Herbal Products. ASEAN Marketing Journal, Vol.VII, No. 2. Pp 104-115.

Willums J. O., (1998), The Sustainable Business Challenge, A Briefing For Tomorrows Business Leaders, Greenleaf publishing, 1998 pg. 137-158, 191.

Yazdanifard, R., and Erdoo, M.I., (2011), The impact of green marketing on customer satisfaction and environmental safety, International Conference on Computer Communication and Management, Proc of CSIT vol.5, IACSIT Press, Singapore. 